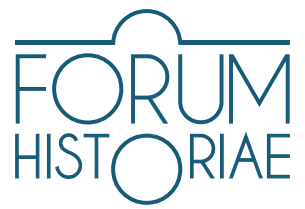

\title{
Networking and Trust During the Cold War (An Introduction)
}

\author{
Adam Hudek - Marína Zavacká
}

\begin{abstract}
HUDEK, Adam - ZAVACKÁ, Marína. Networking and Trust During the Cold War (An Introduction).

The article examines different concepts of the term "trust" within the social sciences, summarising the most important attitudes of experts on the importance of trust in modern societies. Trust and distrust have continually influenced the structure of social hierarchies and been decisive factors for acceptance, exclusion, and control. This analysis focuses primarily on the phenomenon of political and interpersonal trust-or the lack thereof-in both democratic and communist regimes. In geographic terms, the text is anchored in Czechoslovakia and neighbouring soviet satellites, with a slight overlap of selected African countries. It deals predominantly with the bilateral relationships between citizens and political institutions, and between institutions and their representatives, especially during transition periods following political crises.
\end{abstract}

Keywords: Political trust, distrust, networks, Cold war, dictatorship, social history, 20th century history, Communism, democratization

DOI: https://doi.org/10.31577/forhist.2021.15.2.1

$\mathrm{T}$

rust as a bond within human communities, from families to international organizations, and also in terms of political life has become a significant research topic for social historians. For social scientists, the concept of "trust" is, by far, not a new term and is generally viewed as an essential piece of any study. As Kenneth Newton, Dietlind Stolle and Sonja Zmerli observed in their article Why Social and Political Trust Are Important, "the importance of trust in government has been well recognized for some 2,500 years, at least since Confucius observed that the ability to rule rests on the foundations of weapons, food, and trust". ${ }^{1}$ In Europe, the modern concept of trust was introduced by John Locke. For him, it is closely connected with the sovereignty of people and no political society or legitimate government can function without the trust of people. ${ }^{2}$ For Marxists as well, trust is of prime importance for a functioning society, though according to the Marxist view, the existence of rational trust depends on creating a structurally just social order and eliminating exploitation. ${ }^{3}$

The research used in this study was carried out in the scope of the grant VEGA 2/0140/18 "Trust and distrust in political environment of the Cold War Europe".

1 NEWTON, Kenneth - STOLLE, Dietlind - ZMERLI, Sonja. Why Social and Political Trust Are Important. In USLANER, Eric M. (ed.) The Oxford Handbook of Social And Political Trust. Oxford : Oxford University Press, 2018, p. 37.

2 See: LOCKE, John. Second Treatise of Government. Indianapolis : Hackett, 1980.

3 DÜNN, John. Trust and Political Agency. In Diego Gambetta (ed.) Trust. Oxford : Oxford University Press 1988, p. 73-93. 
The majority of social scientists agree that contemporary liberal democracies cannot function without trust in the form of social capital. ${ }^{4}$ According to Václav Havel:

The state is not something unconnected to society, hovering above or outside it, a necessary and anonymous evil. The state is a product of society, an expression of it, an image of it. It is a structure that a society creates for itself as an instrument of its own self-realization. If we wish to create a good and humane society, capable of making a contribution to humanity's coming to its senses, we must create a good and humane state. ${ }^{5}$

In this process, trust is inevitable. However, even autocracies and dictatorships cannot function on fear alone or the promise of material wellbeing without a modicum of trust between rulers and the ruled, which also aids in securing compliance. Anthony Giddens, one of the most influential scholars on this topic, underlines the importance of trust among the specific condition of modern societies, considering reflexivity, globalization and level of risk. ${ }^{6}$ Regarding the research of modern societies, Barbara A. Miszal writes:

The interest in trust has not been limited to disputes about how to confide in institutions but has related to debates as to how to project qualities of trust and cooperation on to the state and the market. Trust is no longer seen as a regulatory mechanism; but rather as a public good. ${ }^{7}$

As Ute Frevert reminds us, contrary to the concept of legitimacy or loyalty, "trust" is not only an analytical term but is also used in everyday speech. Here, the term becomes blurry and vague in the sense that there is a difference between ordinary and scholarly meanings. ${ }^{8}$ In addition, while scholars agree on the essential role trust plays as a concept in social theory, they do not necessarily agree on the meaning of the term. Regarding a specific definition of political trust and mistrust, authors of published studies accept Luhmann's inclusive approach, ${ }^{9}$ based on a wide definition of trust as a constituting element of historical action pervasive in all levels of civic life. Political trust is understood in this context as a mutual relationship between the public and political institutions, or as well between different groups and levels of political representatives, from local to international. A certain level of ambiguity thus remains as a unifying feature of the issue.

The concept of trust is traditionally closely connected with that of legitimacy. In such theories, trust in institutions is a prerequisite for their legitimacy and "is associated with political participation and consent". ${ }^{10}$ According to Barbara A. Misztal:

The notion of trust is also being increasingly used by social researchers in an attempt to explain the empirical differences in achieved levels of cooperation in various social and political environments. ${ }^{11}$

4 BEHRENDS, Jan C. Soll und Haben Freundschaftsdiskurs und Vertrauensressourcen in der staatssozialistischen Diktatur. In FREVERT, Ute (ed.) Vertrauen. Historische Annäherungen. Göttingen : Vandenhoeck \& Ruprecht, 2003, p. 338.

5 HAVEL, Václav. A dream for Czechoslovakia. In The New York Review of Books, 1992, Vol. 39, No. 12, p. 13.

6 See: GIDDENS, Anthony. Modernity and Self-Identity. Cambridge : Polity Press, 1991.

7 MISZTAL, Barbara A. Trust in Modern Societies. The Search for the Bases of Social Order. Cambridge : Polity Press, 1996, p. 2.

8 FREVERT, Ute. Vertrauen - eine historische Spurensuche. In FREVERT 2003, Vertrauen, p. 67.

9 LUHMANN, Niklas. Trust and Power. Chichester: Wiley, 1979, p. 88.

10 MISZTAL 1996, p. 245.

11 MISZTAL 1996, p. 2. 
In modern, multicultural or multinational societies that are experiencing political and economic changes or crises, and are threatened by emigration, immigration, religious or ethnic conflicts, the building of interpersonal, institutional and political trust is considered essential in establishing social cohesion. ${ }^{12}$

This issue of Forum Historiae carries a central theme of Networking and Trust, providing an analysis of a range of "experiences with trust". The topic of political trust and distrust is explored, and trust relationships between citizens and political institutions, and between institutions and their representatives are analysed, especially in the wake of political ruptures. There is a focus on the Cold War era, however, in some cases continuities in developments overlap the given period. In a certain way, it was inspired by the UCL SSEES 2012 Conference on Trust and Distrust in the USSR ${ }^{13}$ and its 2013 sequel, which presented a wider research focus including the former Eastern Bloc.

In the research of trust from a historical point of view, it is evident that time plays a crucial role. "It needs no more than a cursory inspection to show that the theme of trust involves a problematic relationship with time," noted German sociologist Niklas Luhmann, author of what is considered the canon on the subject, Trust, published in $1968 .{ }^{14}$ Trust is a matter of the present moment, and it influences the future. Though he stresses, "it needs history as reliable background. One cannot confer trust without all previous experiences." ${ }^{15}$

\section{Trust in Communist East-Central Europe}

It is symptomatic that scholarly interest in the concept of trust relates to the rapid political and social changes after the fall of communist regimes in the former Eastern Bloc. One of the most significant examples is a cultural and economic comparative analysis from Francis Fukuyama entitled Trust: The Social Virtues and The Creation of Prosperity. The author stresses the significance of social capital and cultural capacity to create large and flexible networks of trust within the growing global economy. ${ }^{16}$ Another piece from Polish sociologist Piotr Sztompka, Trust: A Sociological Theory, discusses political trust as the constitutive element in society and is based on experiences with the late communist regime and subsequent transformation. Sztompka points out that "the close, solidaristic community of citizens, committed and loyal toward political authority, could not exist without horizontal trust toward each other as well as vertical trust toward public institutions."17

According to British expert on Russian history Geoffrey Hosking ${ }^{18}$, the collapse of the communist regimes and problematic transition towards the Western market economy clearly showed a need to research the historical context of "trust" as a social phenomenon.

Hosking noted a paradox of the fall of institutions, which were in the long term both outwardly stable and generating stability until they, in the view of many contemporary Sovietologists, "suddenly" collapsed. His interest in an earlier period of Soviet history, appropriate due to the low levels of trust, the Stalinist 1930s, led Hosking to further study

12 NEWTON - STOLLE - ZMERLI 2018, p. 38.

13 Trust and distrust in the USSR. Special issue of The Slavonic and East European Review, 2013, Vol, 91, No. 1.

14 LUHMANN, Niklas. Vertrauen: Ein Mechanismus der Reduktion sozialer Komplexität. Stuttgart : Enke, 1968.

15 LUHMANN 1979, Trust, p. 20.

16 See: FUKUYAMA, Francis. Trust: The Social Virtues and The Creation of Prosperity. New York : The Free Press, 1995.

17 SZTOMPKA, Piotr. Trust: A Sociological Theory. Cambridge : Cambridge University Press, 2003, p. 15.

18 See: HOSKING, Geoffrey. Trust: a History. Oxford : Oxford University Press, 2014. 
mechanisms of building and maintaining public confidence in institutions and the use of national and ethnic symbols. According to his observations, historians pay too much attention to power and tend to neglect trust. ${ }^{19}$ Such a shift in focus should enable a better understanding of social processes in the past and present alike. He also reveals an important moment in the weighing of trust, which can be strong or weak regarding the extent of risk and value of committed resources, and also thick or thin in terms of the depth of knowledge and intensity of contact with the person or institution one trusts. ${ }^{20}$ Hosking offers a valuable observation on strong, thin trust as gradually prevailing, but it is often erroneously interpreted as absent:

We misunderstand the nature of trust today because we have not realized that strong thin trust has become the dominant mode. It is more reliable and all-embracing, but less "warm" and personal than thick trust, hence we feel trust has declined. ${ }^{21}$

According to the traditional view, the socialist dictatorships did not need to be concerned with legitimacy, support or the trust of citizens in the system because they had the means to suppress any signs of dissatisfaction or calls for change..$^{22}$ As Diego Gambetta observed, societies relying on the use of force and coercion tend to be less efficient, more costly and generally more unpleasant than those with high levels of trust. ${ }^{23}$ According to such an argument, the disintegration of the Soviet system proved that the weakness of undemocratic states lies in their lack of social trust. Barbara A. Misztal writes that:

People in communist societies were supposed to trust the system without questioning it, without having a chance to check it, or without even an opportunity to retreat from it. [...] Hence, to trust or not to trust the system was not the individual responsibility as there was no freedom of choice. ${ }^{24}$

It needs to be stressed that political elites during Stalinism also knew the value of trust in society. As William Mishler and Richard Rose demonstrate in their case study Popular evaluation of Civil and Political institutions in post-Communist societies (1997), both democratic and dictatorial power needs to maintain and develop a certain level of popular confidence in institutions. ${ }^{25}$ While democracies depend on it due to their limited use of repressive apparatus, dictatorships-aside from demanding manifestations of trust or at least compliance through pressure-strive to achieve power stability through various collective guarantees (security, living standards, etc.).

The problem is the gap between what was expected and reality. In fact, in communist societies, institutional and political trust as social capital was always in short supply, especially in comparison with Western democracies. ${ }^{26}$ The centralized power of the party-state undermined cooperation, negotiation and respect for anything other than official positions. Pragmatic acceptance and conformism acted as a cover-up for the system. Despite

19 HOSKING 2014, p. 200.

20 HOSKING 2014, p. 47.

21 HOSKING 2014, p. 195.

22 LETKI, Natalia. Trust in Newly Democratic Regimes. In USLANER 2018, p. 338.

23 GAMBETTA, Diego. Can we trust trust? In GAMBETTA, Diego (ed.) Trust: Making and breaking cooperative relations. Oxford : Basil Blackwell, 1988, p. 221.

24 MISZTAL 1996, p. 195.

25 MISHLER, Wiliam - ROSE, Richard. Trust, Distrust and Skepticism: Popular Evaluations of Civil and Political Institutions in Post-Communist Societies. In The Journal of Politics, 1997, Vol. 59, No. 2, pp. 418-451.

26 BEHRENDS 2003, p. 363. 
this, there still was a need for trust, "in response to the unpredictable, hostile institutional environment and severe economic shortages, citizens of communist states formed tight networks of trust and reciprocity they could rely on for everyday provision of goods and for support." ${ }^{27}$ The research of James Mark on the Hungarian middle-class indicates how much the level of political and social trust correlated with stability and strength, namely due to its readiness to carry the risk of trusting "anonymous" institutions and persons unrelated through kinship. ${ }^{28}$ The self-confidence of this strata, based on professional qualifications linked to literacy and often directly to administration skills, also serves as a reservoir of survival skills such as the ability to outwardly conform, invent suitable "new pasts," and form discreet networks of mutual support. With the vertical trust between citizens and the ruling elites destroyed, strong horizontal networks of interpersonal trust and reciprocity were essential for coping with the problems of everyday life. ${ }^{29}$

In this context, the research results of Alexey Tikhomirov are very interesting, namely his search for an answer to the question of whether the trust among society in Soviet Russia was actually low or if it was simply manifested in other ways, unfitting traditional categories and thus escaping attention. In his study on the regime of forced trust in the environment where the Communist party was its sole, (self)declared distributor he asked:

Was it really possible to sustain the viability of a political mechanism for such a long time without trust? What kind of a role did trust play in processes of social integration, disciplining and mobilizing the population politically? ${ }^{30}$

Introducing the term "forced trust", he claims:

Forced trust was based on observation of a ethical-moral codex of honour that joined the state and the population together through bonds of mutual obligations, duty and emotions rather than by the rule of law, civil rights and well-functioning institutions. ${ }^{31}$

Tikhomirov also focused on distrust as a not merely an antonym, signalling the absence of trust, but as an equally constitutive factor in the creation of social hierarchies. He argues that:

Distrust formed a system of coordinates with its own harsh rules of behaviour and rhetoric, cruel methods of control and oversight and its singular practices of inclusion and exclusion, within which a subject could find protection and defense, could identify dangers and opportunities and find meaning in his/her existence and could collaborate with the regime.

Contrary to common expectations, "societies of distrust" do not sink into disruption, containing "a much greater potential for mobilizing the population negatively-using images of 'enemies' - in the state's interests." Tikhomirov concludes that in the political environment of Soviet Russia, distrust was a "key factor in making and conserving the emotional bonds between people and state." 32

27 BEHRENDS 2003, p. 340.

28 MARK, James. Discrimination, Opportunity, and Middle-Class Success in Early Communist Hungary. In The Historical Journal, 2005, Vol. 48, No. 2, pp. 499-521.

29 TIKHOMIROV, Alexey (ed.), Trust and Distrust under State Socialism, 1953-1991, A Special Issue in Journal of Modern European History, 2017, Vol. 15, No. 3.

30 TIKHOMIROV, Alexey. The Regime of Forced Trust: Making and Breaking Emotional Bonds between People and State in Soviet Russia. In Slavonic and East European Review, 2013, Vol. 91, No. 1, p. 80.

31 TIKHOMIROV 2013, p. 80.

32 TIKHOMIROV 2013, p. 83. 
Case studies on the situation in Czech universities are extremely relevant, especially in the research of discourse and acts of political distrust. These works analyse the mechanisms and formal rituals of "expulsion from the collective" during the purges at the beginning of the Normalisation era. ${ }^{33}$

\section{Trust and Democratization}

Although the central research issues were different initially in the context of post-communist democratisation (performance, economy, robustness of the institutions), the level of political trust very soon became recognised as "something necessary for new democracies to last". ${ }^{4}$ Thus, the concept of trust became essential in research of the transition towards democracy. For many scholars, the post-communist democratisation clearly underlined the importance of trust and provided "insight into both the necessity and the difficulty of generating social cooperation based on trust." ${ }^{35}$ Ethnologist and historian Michail Guboglo in his analysis of the mutual relationships of trust and justice in the background of the political mechanism of the ethnic minority referendum, states that the trigger for interest in the factor of trust in Russian social sciences was its deficit in the 1990s, when many people lost interpersonal trust and thus effective cooperation in ensuring the best possible living conditions in post-communist Russia. ${ }^{36}$ Together with Claus Offe, we can say that the fall of communist regimes also meant a redefinition of social solidarity and the concept of trust. The new democracies faced a lack of "a fixed set of trustworthy, or at least uncontested social facts and binding institutional forces." ${ }^{37}$

Natalia Letki asserts:

While scholars expected that democracies would not automatically generate social and political trust that authoritarian regimes destroyed, they did not expect that democratization would further undermine trust." 38

Although the political distrust generated by communist regimes was replaced by a high level of trust generated by the initial hope in democracy and the expectation of Western economic standards, it was only a short-term development. In Central Europe, and even more in Eastern Europe, the decline of trust occurred surprisingly early. Disappointment with the transition results also drove down the average trust in public institutions (including government, parliament, courts, army, and police) across the post-communist region from the 1990s through the 2010s. The majority of countries in the region have never reversed the profound erosion of public trust that began after 1989. The endemic corruption

33 See: PETRÁŇ, Jozef. Filozofové dělají revoluci. Filozofická fakulta Univerzity Karlovy během komunistického experimentu (1948-1968-1989). Praha : Karolinum, 2015. KAŠKA, Václav. Neukáznění a neangažovaní. Disciplinace členů Komunistické strany Československa v letech 1948-1952. Praha, Brno : Ústav pro studium totalitních režimů, Conditio humana, 2014. VOLNÁ, Katka - JAREŠ, Jakub - SPURNÝ, Matěj - PINEROVÁ, Klára. Prověrená fakulta: KSČ na Filozofické fakultě UK v letech 1969-1989. Praha : Ústav pro soudobé dějiny AV ČR, 2009. HOLÝ, Jiř́i - VOLNÁ, Katka. Tato fakulta bude rudá!: katedra české literatury Filozofické fakulty Karlovy univerzity očima pamětníkư a dokumentů. Praha : Akropolis, 2009. JAREŠ, Jakub - SPURNÝ, Matěj - VOLNÁ, Katka. Náměstí Krasnoarmějců 2: učitelé a studenti Filozofické fakulty UK v období normalizace. Praha : Togga, 2012. JAREŠ, Jakub - SPURNÝ, Matěj - VOLNÁ, Katka. S minulostí zúčtujeme: sebereflexe Filozofické fakulty UK v dokumentech sedmdesátých a devadesátých let 20. století. Praha : Academia, 2014.

34 LETKI 2018, p. 336.

35 MISZTAL 1996, p. 9.

36 GUBOGLO, Mikhail Nikolaevich. Antropologia doveria. Etnosociologicheskie i etnopoliticheskie ocherki. Moscow : Yask, 2016, p. 25.

37 OFFE, Claus. Capitalism by democratic design? In Social Research, 1991, Vol. 58, No. 4, p. 882.

38 LETKI 2018, p. 351. 
of many new democracies proved itself especially an enemy of trust. Dissatisfaction with the economy and the belief that politicians do not care about what people think had the same impact. ${ }^{39}$

\section{Trust and Experts}

Since the economic crisis of 2008-2010, and more recently during the Covid pandemic, it became apparent that the erosion of public trust in Central and Eastern Europe also includes distrust towards scientific institutions and the experts themselves. The same is true for "mainstream" media and all types of traditional elites. "The rationality of technocrats, scientists and administrators is questioned and their concept of 'public good' is rejected." 40 This is a problem because in a highly complex society, experts need to have basic credibility to be trusted. In modern society, trust in the experts and especially in their expertise, is a sine qua non of their proper performance. ${ }^{41}$ On the other hand, the growing criticism of science's irrational and destructive practices has led to a disintegration of the consensus on progress and the monopoly of science. ${ }^{42}$ The negative consequences of this development are visible not only in the Central Eastern Europe, but also in many Western countries.

\section{Content of the Issue}

This issue of Forum Historiae aims to explore the relationship of trust between citizens and political institutions, as well as between institutions and their representatives, especially in the wake of political ruptures. Authors sought to analyse the phenomenon of trust and distrust across the East-West borders in the sphere of economic, cultural and scientific relationships and the émigrés circles. Studies deal with the majority of issues mentioned in this introduction, with a primary focus on the following:

- The development and maintenance of networks of trust in typologically differentiated environments.

- Survival strategies, performing loyalty, earning political credibility and trust in socialist dictatorships.

- The roles of symbols, rituals and narratives in building and maintaining trust within and across bodies involved in official and unofficial structures.

- The rhetoric of the mutual non-threat - international and domestic.

- Restoration of relationships in workplaces in times following political purges.

- Trust in the expert milieu - continuity in discontinuity.

- The phenomenon of trust and distrust in the emigré circles - gaining the trust of the "West" and at home after 1989.

- Trust between East and West - traveling, scientific relations, international trade, culture, globalization.

39 van der MEER, Tom - DEKKER, Paul. Trustworthy states, trusting citizens? A multilevel study into objective and subjective determinants of political trust. In ZMERLI, Sonja - HOOGHE, Marc (eds.). Political Trust: Why Context Matters. Colchester : ECPR Press, 2011, pp. 95-116.

40 MISZTAL 1996, p. 266.

41 WEISKER, Albrecht. Expertenvertrauen gegen Zukunftsangst Zur Risikowahrnehmung der Kernenergie. In FREVERT 2003, p. 397.

42 MISZTAL 1996, p. 265. 
The issue presents eight studies on topics of Czechoslovak and Polish history. Jozef Hyrja provides a case study of individual Holocaust survivors who failed to regain Czechoslovak citizenship after World War II due to a specific ethnic definition of eligibility and found themselves "stateless." He illustrates the complex relationship between an individual and institutions, as well as the question of mutual trust and mistrust through the emigration process. The Schwarz family's attempt to emigrate from Czechoslovakia with the assistance of intermediary organizations provides a wealth of insight into the (dis)function of the state and its administration after the war, during a time of defining the country's approach to specific minority groups. This study details the chain of interlinked events and shifting loyalties that often occurred between individuals, intermediaries, donors or sponsors and the state.

Zuzana Panczovás analysis Conspiracy Theories and Rumours as Key Elements of Political Propaganda in the 1950s shows how rumours and gossip are often essential communication devices in civil society. Their influence tends to intensify in times of social crises and long-term conflict. The Cold War took place in an almost apocalyptic atmosphere, where fear of an outbreak of a fatal nuclear conflict permeated society. On both sides, combat occurred on a psychological level as a way to gain the trust and sympathy of citizens. The dividing line between East and West was also a demarcation between two frequently reflected images of the enemy presented by representatives of state power and the state-controlled media. However, there was also a less manageable spontaneous public debate, which reacted to the intervention of state supervision, questioned official interpretations and sought its own answers to important social events.

Jerzy Kochanowski researches relationships between the government and society during the era of so-called real socialism by presenting the example of private initiatives in tourism by highlanders from the Podhale Region. With millions of visitors every year, the city of Zakopane has become the biggest tourist centre in Poland since the 1950s. This was due to the expansion of private enterprise by local highlanders that was independent from the "state" sector, creating a clientelist network involving such actors as party functionaries, policemen, and people employed in the justice system, inland revenue, customs, etc. The result of the author's findings is a fascinating documentation of the spaces for manoeuvre in the era of real socialism involving "private" and "state" actors, thus challenging the totalitarian paradigm.

Vítězslav Sommer examines the role of social scientific expertise in Czechoslovakia during the building and governance of the socialist state. In the 1950s, the new social sciences that helped build the institutions and rules of the new regime were established. The roles of social scientists as experts during the reform era of the 1960s and the socalled consolidation regime of the 1970s are analysed, and the 1980s are characterized as a period when the unequal alliance of the social sciences and the socialist state fell apart. The article demonstrates that studying the relationship of state policies towards social scientific expertise deepens our understanding of state socialist rule. Scrutinizing the responses to demands imposed by the state and the Communist Party of Czechoslovakia on academia and expertise provides a fresh perspective on the attitudes of the educated middle class towards socialism as a political project and an everyday reality. 
In her article Building and Testing Trust Within a Socialist Dictatorship: The Case of Czechoslovak Experts in Africa Pre and Post-1968, Barbora Buzássyová explores the foundations of trust between Czechoslovak state bodies and experts who were selected for foreign service in Africa. The primary focus is on the means through which this faith was challenged during long periods of separation from socialist ways of life, which was reinvented after the systemic political changeover in the Czechoslovak administration after August 1968. Drawing on the concept of "navigation," the experts developed strategies to earn and restore credibility in the eyes of party authorities after the total disintegration of previous networks of trust following the Warsaw Pact invasion of Czechoslovakia. During their tenure abroad, experts established trust networks on various levels; not only with Czechoslovak political representatives but also colleagues in their agencies and even officers of the Czechoslovak Intelligence Service. These personal ties proved to be instrumental for negotiating future career prospects after the stormy years of 1968-1969.

Kristina Andělovás piece, The Genesis of Political Distrust of the So-Called Sixty-Eighters After 1989, describes the political trajectories of the Prague Spring communist functionaries. These politicians-the so called socialist opposition-represented an important part of the Czechoslovak democratic opposition in the 1970s and 1980. Even though many reform communists also stood at the inception of Charter 77, non-communist dissent was politically distrustful of the socialist opposition. Unlike the "non-political" Charter 77, Czechoslovak socialist opposition has always advocated a profiled political program of democratic socialism. Even so, distrust towards reform communists persisted after 1989.

Agáta Š́stová Drelová investigates the central theme concepts in her article, Trust in the Church Hierarchy Among the Underground Church Community in Post-1968 Slovakia. With the church hierarchy under tight state control and effectively existing on two levels-officially and "underground" - the level of trust fluctuated and the character changed. Trust was something constructed, challenged and negotiated. Drawing from an analysis of catholic discourse in the late socialist period, the character and level of trust in the local catholic hierarchy changed dynamically according to the present day power structure's relationship with the communist party-state, its relationship with the Vatican and the level and quality of the hierarchy's relationship with the underground community itself.

In the article Understanding Democratic Trust and Legitimacy Through the Eyes of the Public Against Violence After the Fall of the Communist Regime in Czechoslovakia, Matej Ivančík shows how gaining trust both domestically and internationally became a self-evident feature of the 1989 democratic revolution protagonists' activities. Thus, it was present within their very policies aimed at political and economic transition. Unlike Poland or Hungary, whose transition legitimization was framed by the so-called Round-Table Talks, the revolutionaries in Czechoslovakia had to derive legitimacy directly from the very event of the "Velvet Revolution." This exposed their policies to a participatory scrutiny of sorts in an even more imminent manner. To gain trust, something at best transferable to actual political results, i.e. winning the election, the proponents of the democratic revolution in Czechoslovakia engaged in 
both policies and politics which would create an environment most preferable to their goals. The article focuses on the political languages of ethics and politics, totalitarianism and Europeanization, and aims at understanding how the environment of gaining trust worked in the Slovak case.

\section{Conclusion}

The main goal of this article is to provide an overview of the most common and popular interpretations of the concepts of trust and mistrust. The quoted works provide useful concepts and elaborated theoretical frameworks which have already been applied in case studies or comparisons involving states, institutions or individuals. A number of these approaches are also employed in this issue of Forum Historiae. The ambition of these authors is a shift in research regarding political trust and mistrust towards a socio-historical analyses, including interpretations of sources traditionally exploited by authors of political history and the history of diplomacy.

This issue covers the given phenomena within a variety of environments, from the creation and renewal of basic working relationships in workplaces affected by a wave of political purges, to the reopening of international negotiations after serious diplomatic conflicts.

The published texts focus on political trust and distrust as a pervasive and constitutive element on all levels of civic life, focusing mainly on the bilateral relationships between citizens and political institutions, as well as between institutions and their representatives, especially during periods following significant political crises.

Considering the current state of knowledge regarding the topic of trust and mistrust in East-Central Europe, it is only understandable that these presented studies did not explore all key topics, not by far, which will require many years of focused and systematic research. Despite their heterogeneity, however, the case studies published in this issue offer intriguing insight into the analysis of trust and distrust in the East-Central European region during the second half of the 20th century.

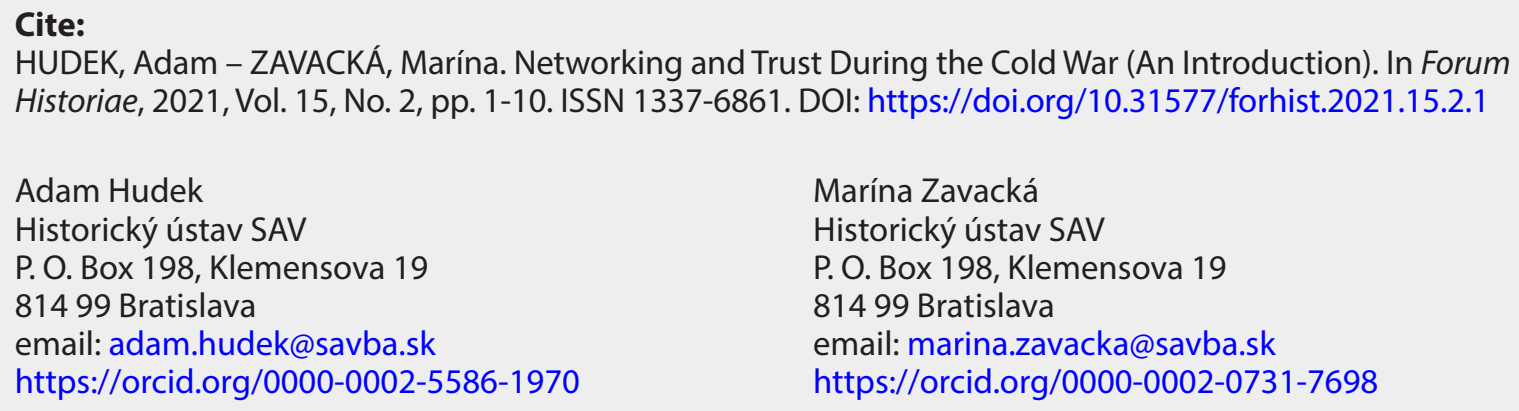

